\begin{tabular}{|l|l|l||}
\hline \multicolumn{2}{|c|}{ PublisherInfo } \\
\hline \hline PublisherName & $:$ & BioMed Central \\
\hline \hline PublisherLocation & $:$ & London \\
\hline \hline PublisherImprintName & $:$ & BioMed Central \\
\hline \hline
\end{tabular}

\title{
Plant wound responses
}

\begin{tabular}{|l|l|l||}
\hline \multicolumn{2}{|c|}{ ArticleInfo } \\
\hline \hline ArticleID & $:$ & 3638 \\
\hline \hline ArticleDOI & $:$ & $10.1186 /$ gb-2000-1-2-reports0061 \\
\hline \hline ArticleCitationID & $:$ & reports0061 \\
\hline \hline ArticleSequenceNumber & $:$ & 35 \\
\hline \hline ArticleCategory & $:$ & Paper report \\
\hline ArticleFirstPage & $:$ & 1 \\
\hline \hline ArticleLastPage & $:$ & 4 \\
\hline \hline & & RegistrationDate : 2000-6-27 \\
ArticleHistory & $:$ & Received \\
\hline \hline ArticleCopyright & $:$ & BioMed Central Ltd2000-6-27 \\
\hline \hline ArticleGrants & $:$ & \\
\hline \hline
\end{tabular}




\begin{tabular}{|l|l|l|}
\hline ArticleContext & $:$ & 130591122 \\
\hline
\end{tabular}

\section{Thomas Eulgem}

\section{Abstract}

The existence of several distinct plant signaling pathways regulating changes in gene expression in response to wounding has been demonstrated using cDNA microarray analysis.

\section{Significance and context}

Being sessile, plants are subject to various types of physical damage from insect feeding, wind, hail and other environmental stresses. Such damage is commonly referred to as wounding. The complex responses of plants to wounding have been extensively studied in recent years, and numerous woundresponsive genes have been identified in various species. The phytohormones ethylene and jasmonic acid (JA) and some of its derivatives have been implicated in the regulation of such genes. Using a cDNA microarray with 150 selected Arabidopsis thaliana expressed sequence tags (ESTs), Reymond et al. performed a comparative gene expression profiling analysis with various distinct wound-related stimuli in wild-type Arabidopsis as well as in two Arabidopsis signaling mutants.

\section{Key results}

A time-course study of mechanically wounded Arabidopsis leaves revealed groups of genes with similar expression behavior. Among the earliest responses was the activation of various genes implicated in pathogen resistance, including $P R-1, P R-2$ and $P R-5$, as well as two genes encoding mitogen-activated protein kinases (MPK3 and MEKK1). The early activation of a set of genes with a potential function in defense could reflect the need to prevent opportunistic pathogen infections at open wounds. Another group of co-regulated genes includes two genes encoding enzymes involved in JA biosynthesis (LOX2 and AOS). Interestingly, the temporal expression pattern of these genes coincides with the kinetics of JA accumulation after wounding, suggesting a causal relationship between LOX2 and AOS transcript accumulation and JA biosynthesis.

Using the JA-insensitive Arabidopsis mutant coil, the authors could categorize wound-responsive genes into two basic classes: a class of COI1-dependent genes for which activation, or repression, by wounding appears to be mediated by JA; and a class of COI1-independent genes whose woundresponsiveness appears not to be mediated by JA. To identify a potential signal involved in the regulation of the COIl-independent group of genes, ethylene was investigated. Surprisingly, expression 
of none of the wound-responsive genes analyzed in this study was substantially altered in the ethyleneinsensitive ein2-1 mutant as compared to wild-type plants. Thus, ethylene plays no essential role in the regulation of the large number of wound-responsive genes examined in this study.

Dehydration of the leaves was found to induce expression of many wound-inducible genes, including 13 COI1-independent genes. Hence, water stress as a result of tissue damage might constitute a distinct stimulus responsible for the activation of some genes after wounding. Only a subset of genes activated by artificial wounding was activated in response to insect feeding by larvae of the cabbage white butterfly Pieris rapae however; and feeding of these larvae had little effect on water stress-inducible genes. The authors suggest that these profound differences might result from the specific feeding strategy of $P$. rapae larvae, which avoid generating large surfaces of crushed leaf tissue, thereby minimizing water stress within the leaves. This specific feeding behavior may limit the activation of host defense genes to a subset that has no significant impact on insect fitness.

\title{
Links
}

Supplementary information to Plant Cell 12:707-719 including technical details about the cDNA microarrays used, can be accessed from the Farmer research group website. A comment on this paper appeared in the In this issue section of Plant Cell 12(5) and is available free online.

\section{Reporter's comments}

This study is an interesting example of the dissection of a regulatory pathway based on the economical use of cDNA microarrays representing only a limited number of genes. The high reliability of this study was demonstrated by multiple repetitions (up to nine) of selected experiments.

\section{Table of links}

\author{
Plant Cell
}

Supplementary information to Plant Cell 12:707-719

Farmer research group

In this issue section of Plant Cell 12(5) 


\section{References}

1. Reymond P, Weber H, Damond M, Farmer EE: Differential gene expression in response to mechanical wounding and insect feeding in Arabidopsis. Plant Cell. 2000, 12: 707-719. 1040-4651

This PDF file was created after publication. 